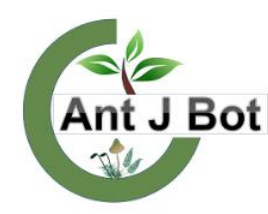

Received : 12.10 .2020 Accepted : 10.12.2020 Online : :09.01.2021

\title{
Floristic studies of the pteridophytes of district Tor Ghar KP, Pakistan
}

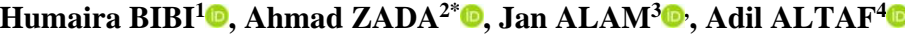 \\ ${ }^{1,3}$ Hazara University, Department of Botany, Mansehra, KP, Pakistan \\ ${ }^{2}$ Yangzhou University, College of Bioscience and Biotechnology, Yangzhou, China \\ ${ }^{4}$ Yangzhou University, College of Agriculture, Key Laboratory of Crop Genetics and Physiology of Jiangsu \\ Province/Wheat Research Center, Yangzhou, China \\ *dh19025@yzu.edu.cn, ${ }^{1}$ humairatanoli93@gmail.com, ${ }^{3}$ bibih2695@gmail.com, ${ }^{4}$ er.altafadil@outlook.com
}

\section{Tor Ghar KP, Pakistan bölgesinin pteridofitleri üzerine floristik çalışmalar}

Abstract: This study was aimed to document the floristic attributes of the pteridophytes of district Tor Ghar; Khyber Pakhtunkhwa, Pakistan. Total 41 species distributed in 20 genera and 10 families were recognized. Dryopteridaceae was the largest family with 12 species (29.26\%). Second and third large family is Pteridaceae and Thelypteridaceae with 10 (24.39\%) and $5(12.19 \%)$ species respectively. Like-wise, Dryopteris was the largest genus with $6(14.63 \%)$ species. The main families were Aspleniaceae, Blechnaceae, Dennstaedtiaceae, Dryopteridaceae, Equisetaceae, Lygodiaceae, Marseliaceae, Pteridaceae, Thelypteridaceae, and Woodsiaceae. Polystichum integrilobium (Ching ex Y.T. Hsieh) W.M. Chu ex H.S. Kung is reported for the first time for Pakistan and 33 species are new records for the Tor Ghar. These identified species were collected from different localities i.e. Shumli Bandi, Bandi, Pabal, Tilli, Panja Gali, Kotkay, Ganga , Judba, Seri Kohani, Tagram, Nabori, Tor Kandow and Kandar (Hussanzai).

Key words: District Tor Ghar; Pakistan; taxonomy; pteridophytes; distribution pattern

\begin{abstract}
Özet: Bu çalışma, Tor Ghar; Khyber Pakhtunkhwa, Pakistan Bölgesi pteridofitlerinin floristik özelliklerini belgelemeyi amaçlamıştır. On familya ve 20 cins içinde dağılım gösteren toplam 41 tür tanımlanmıştır. Dryopteridaceae, 12 türle (\%29.26) en büyük familyadır. İkinci ve üçüncü büyük aile sırasıyla $10(\% 24.39)$ ve $5(\% 12.19)$ tür ile Pteridaceae ve Thelypteridaceae'dir. Aynı şekilde Dryopteris, 6 (\%14.63) türle en büyük cins olmuştur. Asıl familyalar Aspleniaceae, Blechnaceae, Dennstaedtiaceae, Dryopteridaceae, Equisetaceae, Lygodiaceae, Marseliaceae, Pteridaceae, Thelypteridaceae ve Woodsiaceae'dir. Polystichum integrilobium (Ching ex Y.T. Hsieh) W.M. Chu ex H.S. Kung, Pakistan için ilk kez rapor edilmiştir ve 33 tür Tor Ghar için yeni kayıt durumundadır. Teşhis edilen bu türler, Shumli Bandi, Bandi, Pabal, Tilli, Panja Gali, Kotkay, Ganga, Judba, Seri Kohani, Tagram, Nabori, Tor Kandow ve Kandar (Hussanzai) gibi farklı yerlerden toplanmıştır.
\end{abstract}

Anahtar Kelimeler: Tor Ghar bölgesi, Pakistan, taksonomi, pteridofitler, dă̆glım modeli

Citation: Bibi H, Zada A, Alam J, Altaf A (2021). Floristic studies of the pteridophytes of district Tor Ghar KP, Pakistan. Anatolian Journal of Botany 5(1): 1-5.

\section{Introduction}

The term Pteridophytes is a fusion of two Greek words (pteron $=$ feather, phyton $=$ plants) means the plants having feathers like shape of their fronds. These are also known as 'vascular cryptogams' and Carolus Linnaeus (1754) categorized them in the class Cryptogamia. Pteridophytes is a group of spore producing plants, designed by two lineages, one is Lycophytes (club mosses) fronds and Monilophytes or ferns (Pryer et al., 2004; Smith et al., 2006). Presently, pteridophytes comprises of approximately about 300 genera and 9600 ferns and 1400 fern allies around world (Smith et al., 2006). However according to Chapman (2006) about $15 \%$ of all fern and lycophyte species may not yet be known to science, while according to Moran (2008) there are approximately 13.600 species in the tropics with the richest diversity (Kornas, 1993; Linder, 2001). Nearly an updated checklist of Pakistan suggests that there are 206 taxa (194 species; 4 forma; 8 hybrids) distributed in 62 genera and 19 families (Gul et al., 2017).

Systematic studies of pteridophyte flora of Pakistan are not fully done. Previously, few workers have contributed in the exploration of the fern flora of Pakistan. Pteridophyte flora of Kashmir Valley resulted in the discovery of only 90 species and 4 varieties of ferns from Kashmir as their collective contribution (Dar et al., 2002).
Stewart (1972) enlisted about 133 taxa from Pakistan and Kashmir in his catalogue "An Annotated Catalogue of The Vascular Plants of West Pakistan and Kashmir". Later Hope (1903) and Beddome (1892) during their work on the pteridophytes documented 27 species from Chitral and 25 species from British India respectively. Nakaike and Malik (1992) prepared a list of pteridophytes including 82 species of ferns belonging to 30 genera and 18 families of Pakistan. Murtaza et al. (2008) investigated Schizaea dichotoma (L.) Smith and were collected specimens from Neelum Valley. Khan (2011) investigated the pteridophytes of district upper Dir and documented 37 ferns species from the area. Wani et al. (2012) reported 106 taxa of fern and fern allies of Kashmir Valley, Gores and Ladakh. Sundas et al. (2012) documented 36 fern species belongs to 18 genera and distributed in 13 families. Fraser-Jenkins (2012) worked on the pteridophytes of political India and documented a revised list of 337 pteridophytes according to the six higher IUCN categories. Gul et al. (2016) studied traditional uses of 60 taxa of fern and fern allies distributed in 16 families, and 26 genera from district Mansehra KPK, Pakistan. Gul et al. (2017) recorded 178 pteridophyte taxa distributed in 43 genera and 17 families from district Mansehra KPK, Pakistan. In the present study an attempt has been made to analyze the magnitude of the taxa under consideration by using previous literature and field based observations. 


\section{Materials and Method}

\subsection{Study area}

Tor Ghar is a combination of two Pashto words (Tor = Black, Ghar = Mountain) which means black mountain, previously Tor Ghar was known by hindko word Kala Dhaka which is the part of Western Himalayan province (Takhtajan et al., 1986). It lies between, $72^{\circ} 48^{\prime}-72^{\circ} 58^{\prime} \mathrm{E}$ and $34^{\circ} 32^{\prime}-34^{\circ} 50^{\prime} \mathrm{N}$. It is an uneven, mountainous area of about $800 \mathrm{~km}$, surrounded at south by Tanawal and Agror valley, on the east by Tikuari and Nandiar, District Buner to the west and Indus River on north (Mehmood et al., 2015). The single highway passes from Darband to Thakot is $85 \mathrm{~km}$. Tor Garh is part of the Western Himalayan Province of Irano-Turanian Region (Takhtajan et al., 1986). District is elevated to a range from 450 to $3.500 \mathrm{~m}$ (Mehmood et al., 2015).

\subsection{Study Plan}

At initial stage, a detailed literature survey was carried out. Accordingly, a comprehensive field plan was designed, extensive field surveys were arranged in suitable seasons of the year from January-October 2017 in order to study and collect the specimens of ferns and fern allies from the various localities of Tor Garh. During field survey all data was collected related to the habit, type of habitat(s), geographic range, altitudinal range, life form, distribution range and ethnobotanical uses was studied in the natural habitat. The different localities visited were Shumli bandi, Panja gali, Pabal, Tilli, Seri kuhani, Ganga muchcot, Judba, Nabori, Tor kandow, Kandar, Bandagai etc.

\subsection{Identification and Laboratory work}

For identification purposes authentic literature and Flora of China and Flora of North America were consulted. However, the morphological features were studied and found out (length, pinnule size, pinnule number, pinna size, pinna number, hairs, and scale on rachis costae and indusia present or absent). Scales, lens, and stereoscope and high resolution compound microscope were used for identification purposes. For anatomy, cross sections of the material were used. Slides were made for each specimen like spore, sporangia, and rachis. Manual methods and microtome (if available) were also used for this purpose. Digital camera was used for anatomical images.

\section{Results}

In total one hundred twenty plants specimens were collected from various localities of the study area. Based on collected materials, 41 species were recognized having 20 genera and distributed in 10 families. For families, Dryopteridaceae was the largest family with 12 species (29.26\%), followed by Pteridaceae having 10 species (24.39\%). In the remaining 8 families 19 species $(46.34 \%)$ were documented as shown in (Table 1, Fig 1). Genuswise, Dryopteris Adans. was the largest genus with 6 species (14.63\%) (Table 2, Fig 2) followed by Polystichum Roth. with 5 species (12.19\%) of the total plant species. Amongst these taxa 33 were the new records for the study area, while 7 species have been previously reported in the studied area. Habitat wise 13 species are terrestrial which is $31.70 \%, 26$ species are lithophytic which is $63.41 \%$ and 2 species are aquatic which represents $4.87 \%$ of total known species from District Tor ghar (Fig. 3). As for altitude is concerned, 25 species $(60.97 \%)$ are reported from 700-1900. Thirteen species $(31.70 \%)$ are reported from $1901-2300,3$ species $(7.31 \%)$ are reported from 2300-2800 (Fig. 4). Ten species $(24.39 \%)$ of total recorded species from the area are traditionally used to cure ailments.

Table 1. Family wise distribution of pteridophytes in district Tor Ghar

\begin{tabular}{|l|c|c|c|}
\hline Family & Genera & Species & $\begin{array}{c}\text { \% of taxa } \\
\text { in total }\end{array}$ \\
\hline Aspleniaceae & 1 & 3 & 7.31 \\
\hline Blechnaceae & 1 & 1 & 2.43 \\
\hline Dennstatidiaceae & 1 & 1 & 2.43 \\
\hline Dryopteridaceae & 3 & 12 & 29.26 \\
\hline Equisetaceae & 1 & 3 & 7.31 \\
\hline Lygodiaceae & 1 & 1 & 2.43 \\
\hline Marseliaceae & 1 & 2 & 4.87 \\
\hline Pteridaceae & 5 & 10 & 24.39 \\
\hline Thelypteridaceae & 4 & 5 & 12.19 \\
\hline Woodsiaceae & 2 & 3 & 7.31 \\
\hline
\end{tabular}

Table 2. Ten largest genera in the pteridophyte flora Tor Ghar

\begin{tabular}{|l|c|c|}
\hline Genus & No. Species & \% in total \\
\hline Dryopteris & 6 & 14.63 \\
\hline Polysticum & 5 & 12.19 \\
\hline Adiantum & 4 & 9.75 \\
\hline Equisetum & 3 & 7.31 \\
\hline Asplenium & 3 & 7.31 \\
\hline Thelypteris & 2 & 4.87 \\
\hline Pteris & 2 & 4.87 \\
\hline Marselia & 2 & 4.87 \\
\hline Onychium & 2 & 4.87 \\
\hline Diplazium & 2 & 4.87 \\
\hline
\end{tabular}

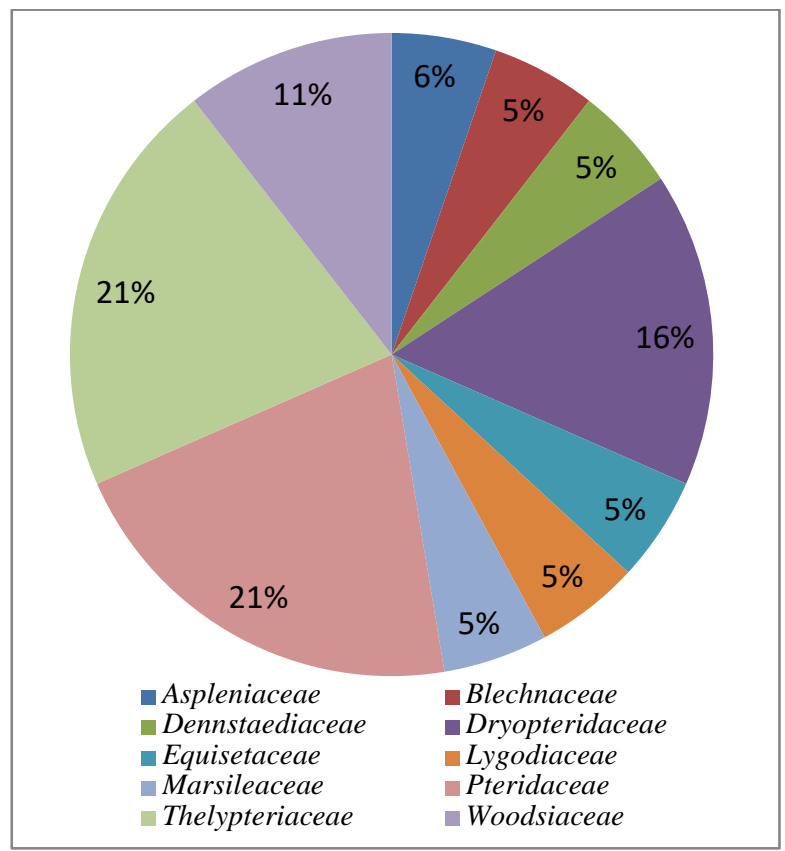

Figure 1. Family-wise distribution of the taxa in district Tor Ghar 


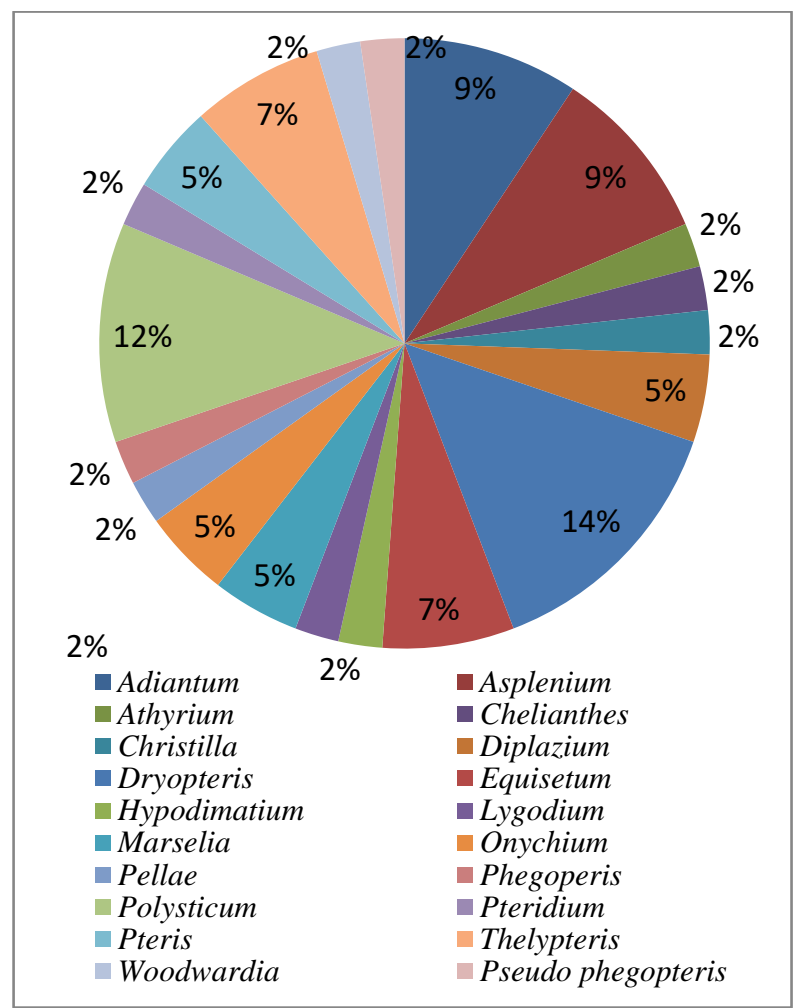

Figure 2. Genus-wise distribution of the taxa in district Tor Ghar

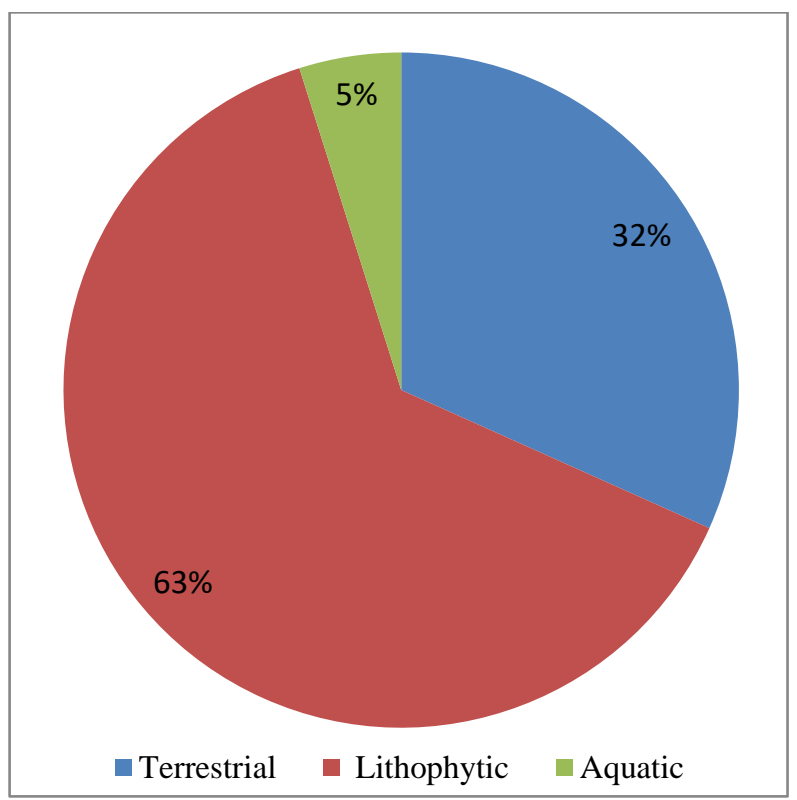

Figure 3. Habitat-wise distribution of the taxa in district Tor Ghar

\subsection{New Generic Record}

Polystichum integrilobium (Ching ex Y.T. Hsieh) W.M. Chu ex H.S. Kung Sin. 36: 244. 1998) (Fig 5)

Plants summer-green. Rhizome erect thickly covered with lanceolate golden to brown scales. Fronds $16 \mathrm{~cm}$; stipe stramineous, $4 \mathrm{~cm}$, ca. $2 \mathrm{~mm}$ in diameter at base scaly, scales dense, narrowly ovate, linear yellow-brownish. Lamina bi-pinnatifid, lanceolate, gradually becomes narrower at base, acuminate; rachis deprived of proliferous bulbils, dense scales both surfaces; stramineous, lanceolate and linear. Pinnae 18 pairs, alternate,

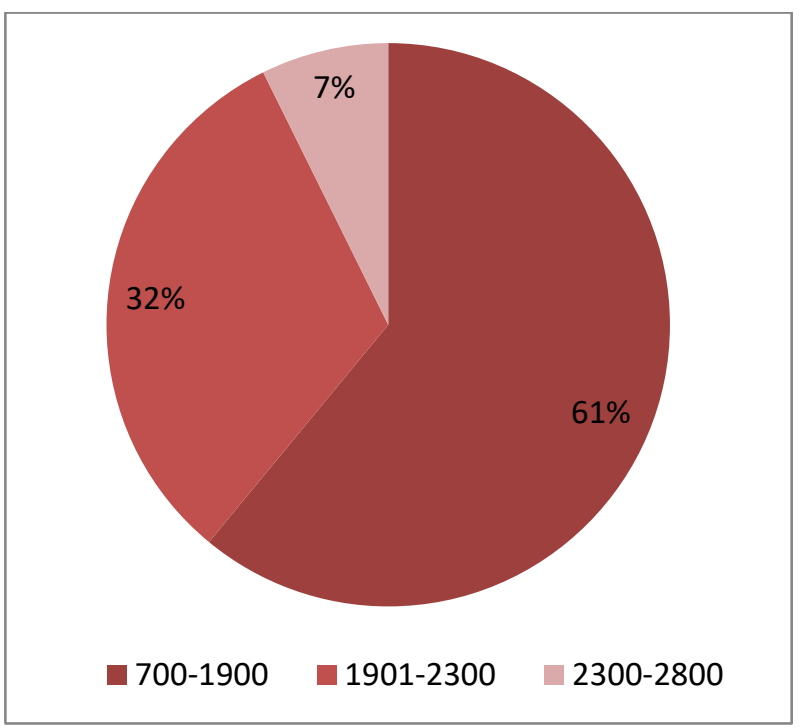

Figure 4. Altitude-wise distribution of the taxa in district Tor ghar

sessile, deltoid to lanceolate, middle pairs $18 \times 7 \mathrm{~mm}$, bases oblique, broadly cuneate, macroscopically auriculate, pinnatipartite, apices obtuse. Lobes 5 pairs, nearly opposite, slightly ascendant, approximate, oblong, entire; many lanceolate yellowish brown microscales on abaxial surface, subglabrous adaxially; frond texture papery; venation pinnate on lobes, inarticulate on both surfaces. Sori in a single row on each side of midrib; indusia serrulate.

Specimens Examined: Tor Ghar; Tilli, 1790 m, 12-072017, Humaira Bibi, Muhammad Irfan 38 (HUP).

Habitat: Near moist and shady place.

General Distribution: North Western Yunnan (China).

\section{Discussions}

District Tor Gar falls in the Irano-Turanian phytogeographical region of Pakistan (Takhtadzhian and Cronquist, 1986). In terms of pteridophyte exploration this region remains neglected. Therefore, an attempt has been made to analyze the magnitude of the taxa under consideration.

In Pakistan, the floristic studies of pteridophytes are still not completed. Most of the work has been done on angiosperms but only a little work is presented on lower plants particularly cryptogams. Recently Tor Gar is little explored in terms of higher plants i.e. angiosperms and gymnosperms (Mehmood et al., 2015). Extensive review of literature revealed that only 16 pteridophytes species are known to the district. However, in current investigation 41 taxa are recorded and these belongs to 20 genera and 10 families. One species is reported for the first time for Pakistan and 33 species are new records for the study area. However, these figures represent about $19 \%$ (species), $30.64 \%$ (genera) and $52.63 \%$ of the total known (families) for Pakistan. Of these, 33 species are new records for the study area. The scientists contributed in exploration of flora of pteridophytes were Ching (1940), Fraser-Jenkins (2012), Sundas et al. (2012), Shah et al. (2019), Nakaike and Malik (1992), Zaman et al. (2019) and Gul et al. (2016). The largest family is Dryopteridaceae having 12 species and 3 genera 
recognized i-e. Dryopteris, Polystichum and Hypodematium Kunze. Dryopteris has 6 species, Polystichum has 5 species and Hypodematium has 1. The same work was done by Gul et al. (2017) and 18 genera were documented. In the current study Thelypteridaceae with 4 genera i.e., Thelypteris Schmidel with 2 species, Pseudophegopteris Ching, Christella H.Lév. and Phegopteris (C.Presl) Fée have 1 species each, and similar research was done by Ching (1940) who documented 12 genera in Thelypteridaceae. Pteridaceae with 9 species and 5 genera i.e. Pteris has 2 species, Adiantum L. has 4 species, Cheilanthes Sw. has 1 species, while Onychium Kaulf. has 2 species and Pellea Link. has 1 species. A similar result was obtained with this work and in general agreement with the work of Fraser-Jenkins (2012) who revised the list of 337 pteridophytes from India. Asplaniaceae has 3 species and 1 genus i.e. Asplenium L. Similarly, Zaman et al. (2012) documented a total of about 36 fern taxa belonging to 18 genera and 13 families. Three species are identified for family Equisetaceae with 1 genus Equisetum L. Shah et al. (2019) documented 8 genera belonged to 4 families of pteridophytes from Chakesar valley at district Shangla Pakistan. Three species are identified for family Woodsiaceae with 2 genera i-e,

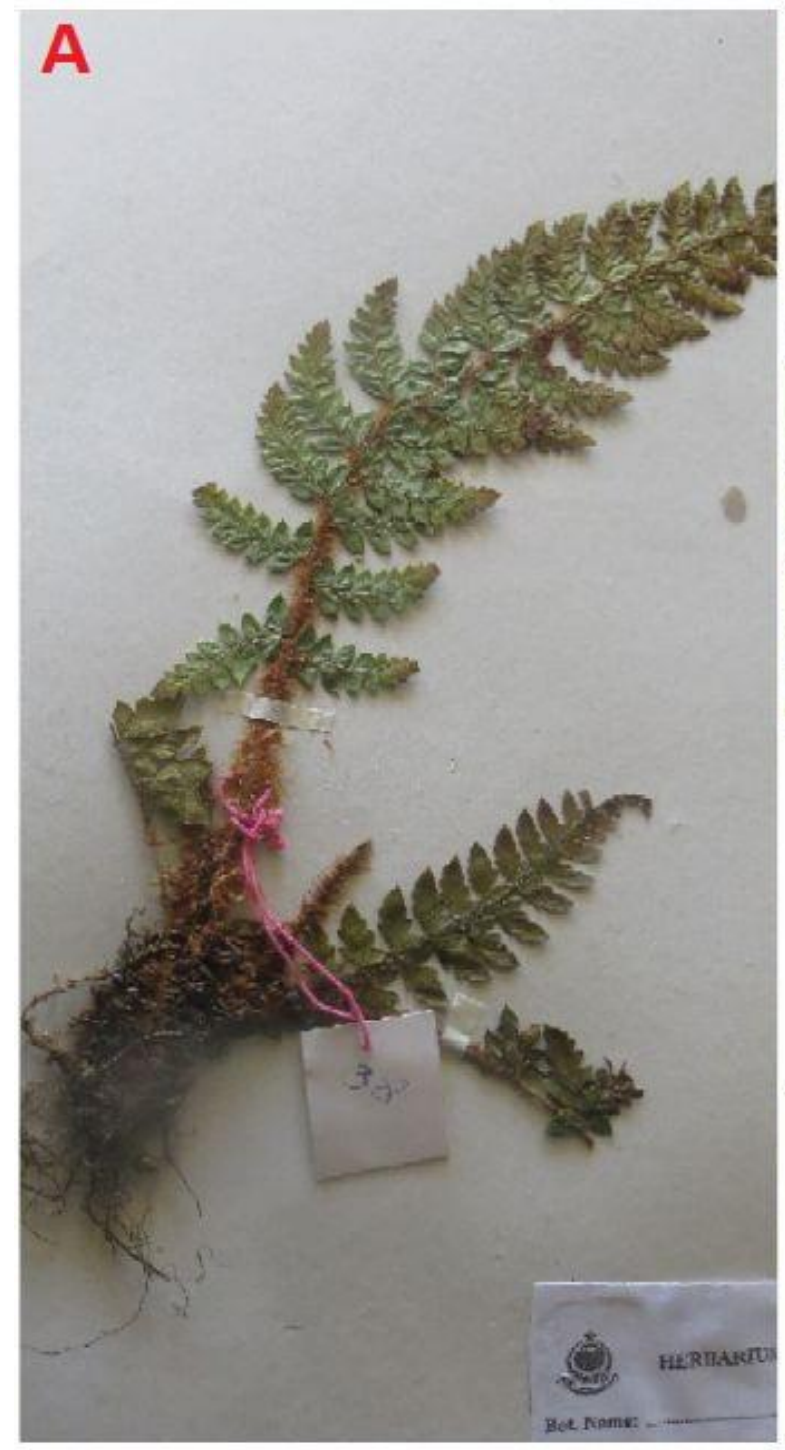

Athyrium Roth has 1 taxon and Diplizium Swartz has 2 taxa. Nakaike and Malik (1992) reported 82 species of pteridophytes belonged to 30 genera, 18 families and distribution pattern from Pakistan. Dennsteadaceae have 1 genus Pteridium Gleditsch ex Scop. and 1 species. The same work was done by Mir et al. (2015) who reported 4 species of pteridophytes for the first time from Kashmir Valley. Two species were identified for family Marsilaceae having 1 genus Marsilea L. The same work was done by Fazal et al. (2014) who collected 25 species of ferns and ferns allies belonged to 13 genera and 8 families for Maidan valley Dir lower district at Pakistan. Lygodiaceae has 1 species and 1 genus i.e. Lygodium Sw. The same work was done by Gul et al. (2016) a checklist of 130 species of ferns and lycophytes distributed in 34 genera and 17 families from district Mansehra, KP, Pakistan were documented. Blechnaceae has 1 species and 1 genus i-e Woodwardia $\mathrm{Sm}$.

\section{Conflict of Interest}

Authors have declared no conflict of interest.

\section{Authors' Contributions}

The authors contributed equally.
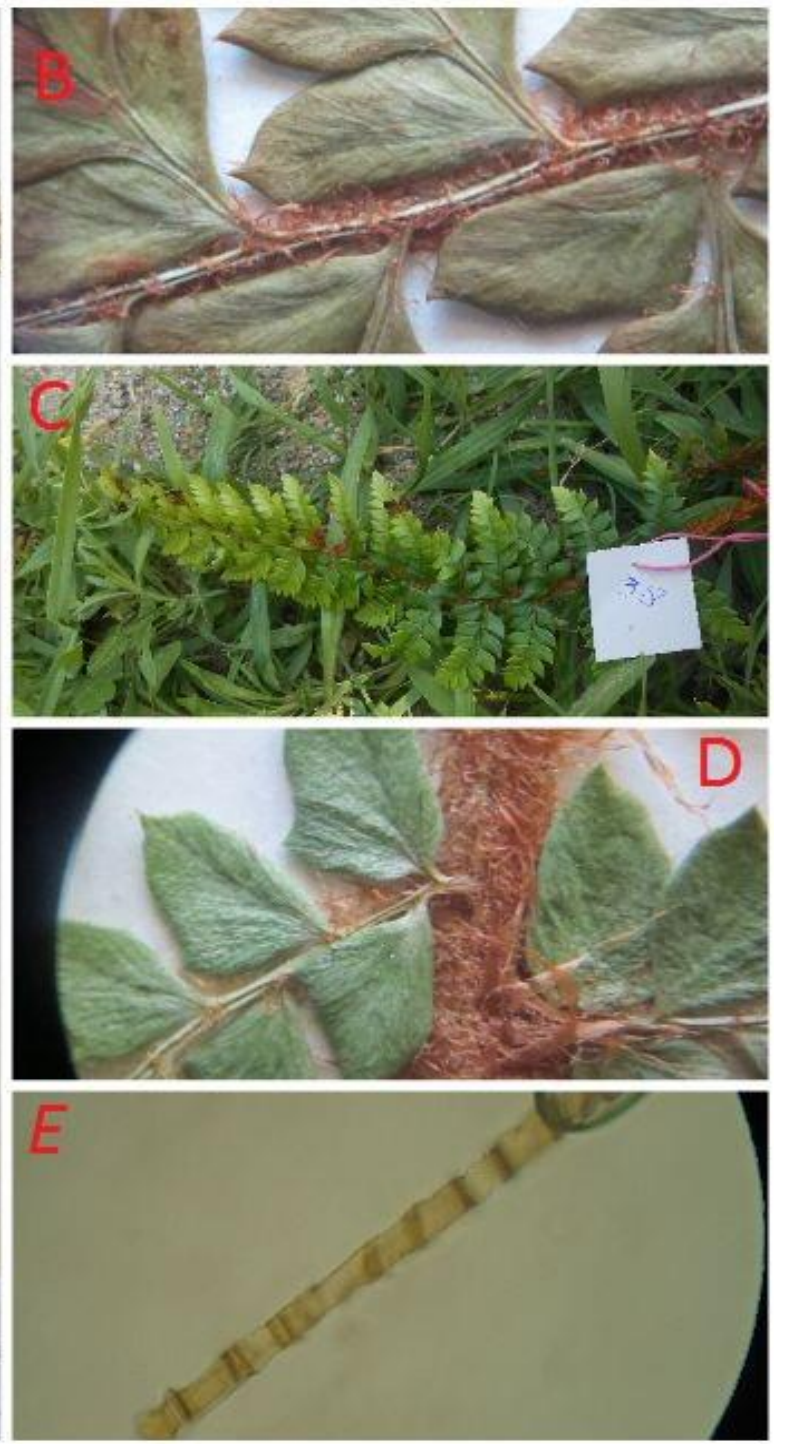

Figure 5. Polystichum integrilobium: A, Close up of frond;B, Closeup of pinna and rachis abaxially; C, Habit; D, Closeup of stipe with scales adaxially; E, Section of scale 


\section{References}

Beddome R (1892). Handbook to the ferns of British India, Ceylon and the Malay Peninsula with supplement. Calcutta: Thacker, Spink, and Co.

Chapman AD (2006). Numbers of Living Species in Australia and the world. Report for the department of the environment and heritage. Canberra: Australian Biolical Resources Study.

Ching RC (1940). On natural classification of the family Polypodiaceae. Sunyatsenia 5: 201-268.

Dar GH, Bhagat R, Khan MA (2002). Biodiversity of the Kashmir Himalaya. Srinagar: Valley Book House.

Fazal U, Asad U, Ali U (2014). Pteridophytic flora of Maidan valley Dir (L) Khyber Pakhtunkhwa, Pakistan. International Journal of Biology Biotechnology 11(4): 649-653.

Fraser-Jenkins CR (2012). Rare and threatened Pteridophytes of Asia 2. Endangered species of India-the higher IUCN categories. Bulletin of National Museum of Nature and Science Series B 38(4): 153-181.

Gul A, Alam J, Ahamd H, Irfan M (2016). An updated checklist of Pteridophytes of district Mansehra, Khyber Pakhtunkhwa, Pakistan. Plant Science Today 3(2): 237-247.

Gul A, Alam J, Majid A, Ahmad H, Qaiser M (2017). Diversity and distribution patterns in the Pteridophyte flora of Pakistan and Azad Kashmir. Pakistan Journal of Botany 42: 83-88.

Hope CW (1903). The Ferns of North-western India including Afghanistan Trans-Indus protected areas \& Kashmir. Journal of the Bombay Natural History Society 14: 720-749.

Khan MS (2011). Diversity of vascular plants, ethnobotany and their conservation status in ushairy valley, distt. Dir (upper) nwfp; northern pakistan. Islamabad: Quaid-i-Azam University.

Kornas J (1993). The significance of historical factors and ecological preference in the distribution of African pteridophytes. Journal of Biogeography: 281-286.

Linder H (2001). Plant diversity and endemism in sub-Saharan tropical Africa. Journal of Biogeography 28(2): 169-182.

Linnaeus C (1754). Genera plantarum eorumque characteres naturales secundum numerum, figuram, situm, \& proportionem omnium fructificationis partium. Leiden: Wishoff.

Mehmood A, Khan SM, Shah AH, Shah AH, Ahmad H (2015). First floristic exploration of the District Torghar, Khyber Pakhtunkhwa, Pakistan. Pakistan Journal of Botany 47: 57-70.

Mir SA, Mishra AK, PALA SA, Reshi ZA, Sharma MP (2015). Ferns and fern allies of district Shopian, Kashmir Valley, India. Biodiversitas Journal of Biological Diversity 16(1): 27-43.

Moran R (2008). Diversity, biogeography, and floristics. Biology and Evolution of Ferns and Lycophytes: 367-394.

Murtaza G, Asghar R, Majid SA, Malik ZH (2008). Morphopalynological and anatomical studies on fan fern Schizaea dichotoma (L.) Smith from Neelum Valley, Azad Kashmir. Pakistan Journal of Botany 40(1): 59-63.

Nakaike T, Malik S (1992). A list of pteridophytes collected from Pakistan in 1990. Cryptogamic flora of Pakistan National Science Museum, Tokyo 1: 261-316.

Pryer KM, Schuettpelz E, Wolf PG, Schneider H, Smith AR, Cranfill R (2004). Phylogeny and evolution of ferns (monilophytes) with a focus on the early leptosporangiate divergences. American Journal of Botany 91(10): 1582-1598.

Shah SN, Ahmad M, Zafar M, Ullah F, Zaman W, Mazumdar J, Khuram I, Khan SM (2019). Leaf micromorphological adaptations of resurrection ferns in Northern Pakistan. Flora 255: 1-10.

Smith AR, Pryer KM, Schuettpelz E, Korall P, Schneider H, Wolf PG (2006). A classification for extant ferns. Taxon 55(3): 705731.

Stewart R (1972).An annotated catalogue of the vascular plants of West Pakistan and Kashmir In: Nasir E and Ali SI (eds.) Flora of West Pakistan. Karachi: Fakhri Press.

Sundas I, Zaheer-ud-Din K, Noreen R (2012). A contribution to the taxonomic study of fern flora of Punjab, Pakistan. Pakistan Journal of Botany 44(Suppl.1): 315-322.

Takhtadzhian AL, Cronquist A (1986). Floristic Regions of the World. Berkeley: University of California Press.

Takhtajan A, Crovello TJ, Cronquist A (1986). Floristic regions of the world. Berkeley: University of California press.

Wani M, Shah M, Naqshi A (2012). The ferns of Kashmir-an update account. Indian Fern Journal 29(1-2): 100-136.

Zaman W, Shah SN, Ullah F, Ayaz A, Ahmad M, Ali A (2019). Systematic approach to the correct identification of Asplenium dalhousiae (Aspleniaceae) with their medicinal uses. Microscopy Research and Technique 82(4): 459-465. 